\title{
Comparative Experimental Studies of Calcium Channel Agonists and Antagonists against Ovariectomy Induced Osteoporosis In Rats
}

\author{
Vijay R. Chidrawar ${ }^{*}$, Krishnapriya Pegalapati ${ }^{2}$, Pavani Ade ${ }^{2}$, Abdulkhaliq J. Alsalman $^{3}$, Shruti Shiromwar ${ }^{1}$ \\ 'Department of Pharmacology and Toxicology, Northern Border University, Rafha, KINGDOM OF SAUDI ARABIA. \\ 2Department of Pharmacology, CMR College of Pharmacy, Hyderabad. INDIA. \\ ${ }^{3}$ Department of Clinical Pharmacy, Northern Border University, Rafha, KINGDOM OF SAUDI ARABIA.
}

\begin{abstract}
Background: $\mathrm{Ca}^{2}+$ channels and calcium signalling appears to play a critical role in the differentiation and functions of osteoclasts and osteoblasts and L-types voltage dependent calcium channels (VDCC) are expressed on bone cells. Either activation or blocking of these channels in bone homeostasis is found to be controversial. Based upon this we have compared effects of VDCC antagonist (-) Verapamil and VDCC agonist (+) BayK-8644 against ovariectomy (OVX) induced bone loss in female Wister rats. Methods: Present study was designed as per the food and administration guidelines for ovariectomy rat model and test drug administration period was 40 days. At the end of the experiment various parameters were compared among the groups. Results: Among all the drugs calcium channel agonist CCA (+) Bay-K-8644 has shown protective effects by increase in the bone density, breaking strength and maintaining serum calcium, phosphorous and ALP level. Calcium channel blockers (CCB) (-) Verapamil has also offered protection in few parameters like bone length but not as good as Bay-K-8644. Conclusion: CCA (+) Bay-K-8644 has of-
\end{abstract}

fered protection may be by reducing opening frequency, current amplitude of Cav 1.2 channels. Moreover it may have elevated cytosolic $\mathrm{Ca} 2+$ in osteoblast cells and decreases RANK-L induced osteoclast formation and bone resorption.

Key words: Bay-K-8644, $\mathrm{Ca}^{2}+$ channels, Osteoblast, Osteoclast, Verapamil.

\section{Correspondence :}

Vijay R. Chidrawar

Department of Pharmacology and Toxicology, Northern Border University, Rafha, KINGDOM OF SAUDI ARABIA.

Phone no: +966-580665011

Email: vijay_pharmacology@yahoo.com

DOI: 10.5530/jyp.2017.9.47

\section{INTRODUCTION}

Osteoporosis is a condition portrayed by diminished bone density, is common among postmenopausal ladies additionally happens in men and women with basic conditions or real hazard elements connected with bone mineralization. Its major clinical manifestations are vertebral and hip fractures, although fractures can occur at any skeletal site. Loss of bone tissue causes deterioration in the architecture of the skeleton, the combination leading to markedly increased risk of fracture. ${ }^{1}$ Osteoporosis is a major and growing public health problem in developed nations. Many women (30-50\%) and men (15-30\%) suffer a fracture related to osteoporosis. $^{2}$

The bone meniralization and resorption are strictly controlled by osteoblast and osteoclast cells. Recently L-type of calcium channels are identified on osteoblast cell line $\mathrm{e}^{3,4}$ but precise role of these channels in bone biology is contradicted, explained below. It's the topic of discussion for many researchers across the world to explore exact role of these existing $\mathrm{Ca}^{+2}$ channels in bone homeostasis. It's well known fact intracellular calcium ions play many roles in human physiology. Few of the earlier research favors that intracellular calcium in osteoblast cells prevents the bone resorption. Calcitonin, IL-4 and protein tyrosine kinase inhibitors suppress osteoclasts activity by acutely increasing the intracellular $\mathrm{Ca}^{+2}$ concentration in osteoblast cells indicating increased intracellular $\mathrm{Ca}^{+2}$ concentration has an inhibitory role in osteoclasts function subsequent bone resorption. Thus, an increase in intracellular $\mathrm{Ca}^{+2}$ concentrations in osteoblast cells is generally accepted as a potential mechanism by which various agents inhibit osteoclasts activity. ${ }^{5-7}$ Moreover, Long et al., 2011 has stated that calcium channel agonist increased the calcium ion threshold for the effective activation of NFATc1 (nuclear factor of activated Tcells) by stimulating $\mathrm{Ca}^{+2}$ ion influx through L-type calcium channels, resulting in decreased osteoclasts formation. ${ }^{8}$ However, Ritchie et al., 1994 has found that dihydropyridine calcium channel blockers are shown to suppress bone resorption by the direct inhibition of osteoclast function. ${ }^{9}$ Parathyroid hormone is one of the key regulator of osteoclastic bone resorption mechanism which was sharply reduced by the treatment of amlodipine a L-type calcium channel blocker. ${ }^{10}$ Even in our earlier research we noticed that CCB has inhibitory role in bone resorption.

From these statements it has been understood that few scientist suggests that CCB's (-) are useful in the management of osteoporosis and few suggesting CCA (+) are useful. Based upon these debatable statements we have used best CCB (-) at the best dose from our earlier experiment i.e. Verapamil $(2.11 \mathrm{mg} / \mathrm{kg})$ and compared with CCA (+) i.e. Bay-K-8644 $(0.05 \mathrm{mg} / \mathrm{kg})$ against OVX induced osteoporosis by considering serum $\mathrm{Ca}^{+2}, \mathrm{P}^{-}$and ALP levels and bone parameters such as bone density, breaking strength, diameter and length. Histopathological examinations were also studied by keeping same experimental conditions.

This is an open access article distributed under the terms of the Creative Commons Attribution-NonCommercial-ShareAlike 4.0 License, which allows others to remix, tweak, and build upon the work non-commercially, as long as the author is credited and the new creations are licensed under the identical terms. 


\section{MATERIALS AND METHODS}

\section{Materials}

\section{Experimental animals: Female Wister Albino rats}

Chemicals: Bay-K-8644 purchased from Sigma Aldrich batch number 112613; Verapamil HCL was used as marketed preparation as Calaptin-40, Piramal Healthcare Ltd, FADA2001; Estradiol valerate was purchased from, local market as Progynon depot inj, Candila Health care Ltd. GM2436; Calcium kit, Transasia Bio-Medicals Ltd; Phosphorous kit, Crest Biosystems; Alkaline phosphatase kit, IRIS Healthcare Tech. Pvt. Ltd.

Instruments and lab wares: Surgical Sutures and catgut (0.2) were purchased from Frank Health Co. Ltd.; Blood collecting vials, Research centrifuge REMI CM - 12; Vernier calipers, MITOTOHO- 532-120; 0.01 sensitivity digital weighing balance, AN ISO 9001; dual energy X-ray absorptiometry (DEXA) apparatus, DEXA 7; Trinacular Microscope, iVU- 3100; Semi -Auto Analyser, ES- 100; Muffle furnace, PMTC- 4040; UV-Visible spectrophotometer, T-70; Flame photometer, PFP7 etc.

\section{Methods}

\section{Selection of the animals}

Thirty female Wistar albino rats of 3-4 months old weighing between 200-250 g were procured from central animal house facility of CMR college of Pharmacy, Hyderabad India. Animals ware maintained under controlled conditions of constant temperature $21 \pm 5^{\circ} \mathrm{C}$ and relative humidity of $50-55 \%, 12: 12 \mathrm{Hr}$ light/dark cycle. The rats were acclimatized for 10 days and have free access to chow and water. CPCSEA guidelines were strictly followed and the project is approved by the Institutional animal ethical committee (IAEC), bearing animal ethical clearance number CPCSEA/1657/IAEC/CMRCP/COL12-14/33.

By observing health statues and normal behavioral parameters for 10 days; healthy, non-pregnant animals were selected for this study by performing veginal smear test. Ovariectomy (OVX) surgery was performed only in 24 female Wistar rats and remaining 6 animals were treated as normal sham operated control. After surgery all the animal were treated with antibiotics and pain killers for three successive days to avoid any postoperative infection and pain respectively. All the operated animals were maintained for 14 days align time for the estrogen deficiency and induction of osteoporosis. Estrogen deficiency was confirmed by performing vaginal smear test on $14^{\text {st }}$ day of the study to confirm a menopausal pattern in OVX rats and dosing was initiated from $15^{\text {th }}$ day of surgery after recording the health status of the animals. ${ }^{11}$

\section{Animal grouping}

Twenty four OVX rats randomly divided into 4 groups by keeping 6 animals in each group while other 6 animals were treated as normal sham operated control. Group 1 sham operated animals were treated with distilled water $(10 \mathrm{ml} / \mathrm{kg}$ p.o. $){ }^{12}$ group 2 OVX animals were treated as distilled water $(10 \mathrm{ml} / \mathrm{kg}$ p.o. $){ }^{12}$ group 3 OVX animals were treated with standard estradiol valorate $(0.1 \mathrm{mg} / \mathrm{kg}, i . m) ;{ }^{13}$ group 4 OVX animals were treated with Verapamil HCL $(2.11 \mathrm{mg} / \mathrm{kg}, \text { p.o. })^{14}$ and group 5 OVX animals were treated with Bay-K-8644 $(0.05 \mathrm{mg} / \mathrm{kg}$, i.p. $) .{ }^{15}$ Selected test and standard drug were administered for successive 40 days in-between 9 to $11 \mathrm{AM}$ to avoid effect of fluctuating neuro-hormonal levels on the drugs. On $41^{\text {st }}$ day various parameters were studied like physical parameters of bone, blood chemistry, histopathological examination and osteoclast count were done.

\section{Ovariectomy surgery procedure}

Ovariectomy surgery was performed as per the U.S. FDA guidelines. Briefly two dorso-lateral incisions were made approximately $1 \mathrm{~cm}$ long above the ovaries and the peritoneal cavity was accessed, the ovaries were identified surrounded by a variable amount of fat. The surgery was done under the blend anaesthesia of i.e. Ketamine $80 \mathrm{mg} / \mathrm{kg}$, Xylazine $5 \mathrm{mg} / \mathrm{kg}$ i.p. The link between the fallopian tube and the uterine horn was cut and the ovary removed out. The stitching was performed by using absorbable catgut 2.0. ${ }^{16}$

Vaginal Smear Test: Vaginal smear cell counts were performed on 100 cells randomly. The percentage of cornified cells was determined according to Cora et. al. 2015 using the following formula: ${ }^{17}$

$$
\text { Percentage of Cornified Cells }=\frac{\text { Cornified Cells }}{\text { Cornified Cells }+ \text { Nucleated Cells }+ \text { Leucocytes }} X 100
$$

There was no significant difference in the percentage of cornified cells between the groups; it confirmed a menopausal pattern in OVX rats.

Determination of Serum parameters and bone parameter: After 40 days of successful dosing on $41^{\text {st }}$ day calcium, phosphorus and alkaline phosphatase (ALP) were analyzed from serum as per the method prescribed by Miller et.al. $1994 .^{18}$

On the same day i.e. on $41^{\text {st }}$ day of the study rats were sacrificed by $\mathrm{CO}_{2}$ overdose using euthanasia chambers and right femur, right tibia and $4^{\text {th }}$ lumbar vertebrae were dissected out from all rats.

Bone Parameters:

Measurement of bone Weight, length and outer diameter of diaphysis right Femur: Dissected right femur was cleaned off to remove all surrounding tissues debris. To achieve the constant weight bone were kept in hot oven at $52^{\circ} \mathrm{C}$ and then weighted on the 0.01 sensitive digital balance. By using digital vernier caliper bone length, outer diameter of diaphysis of right femur and tibia were measured precisely and recorded. ${ }^{13}$

Bone mineral density (BMD) measurement by DEXA apparatus:

Towards the end of the study bone mineral density estimations was performed by utilizing Ex vivo strategy in double blind methodology by utilizing a Hologic QDR-1000 X-beam bone densitometer (double X-beam wellspring of 70 and $140 \mathrm{kVp}$ ) and a ultrahigh determination program with $0.0254 \mathrm{~cm}$ line dividing and a point determination of $0.0127 \mathrm{~cm} .{ }^{19}$

Bone mineral density calculations were done for all isolated right femur and compared with normal control and disease control groups.

Determination of breaking strength: Fresh isolated bones (right femur, tibia and $4^{\text {th }}$ lumbar vertebrae) were kept in breaking strength apparatus (Monsanto) until it cracked and the reading were recorded in Newton's (N). ${ }^{13}$

Histopathology of femur bone and osteoclast examination: was performed as per the methods prescribed by Magda, 2011 and Suzuki et.al. 2010. ${ }^{20}$

\section{Statistical Analysis}

The results are expressed as mean \pm SEM. Comparisons between the treatment groups and positive control; positive control and control were performed by one way analysis of variance (ANOVA) followed by Dunnett's test. In all tests the criterion for statistical significance was $\mathrm{p}<0.05$ (95\% level) and $\mathrm{p}<0.01$ was considered. The analysis was performed by using Graph pad Prism V. 


\section{RESULTS}

Effect of Bay-K-8644 $0.05 \mathrm{mg} / \mathrm{kg}(+)$ and Verapamil 2.11 $\mathrm{mg} / \mathrm{kg}(-)$ on serum calcium and Phosphorous level $(\mathrm{mmol} / \mathrm{L})$ in female Wistar OVX rats

Serum $\mathrm{Ca}^{+2}$ levels declined significantly $(\mathrm{P}<0.01)$ in standard estradiol Valerate, $2.64 \pm 0.09$ and Bay-K-8644, 2.63 \pm 0.04 treated groups when compared to disease control group $2.96 \pm 0.01$. Serum calcium was significantly $(\mathrm{P}<0.01)$ high $2.77 \pm 0.07$ in verapamil treated group compared to Sham operated group. This rise in $\mathrm{Ca}^{+2}$ level is may me because of activation of PTH hormone by the vetapamil.

The serum phosphorous non- significantly decreased in standard estradiol 1.47 \pm 0.06 , Verapamil $1.52 \pm 0.06$ and Bay-K-8644 1.69 \pm 0.08 treated group when compared to disease control group $1.71 \pm 0.1$. (For results please refer Figure 1).

Effect of Bay-K-8644 $0.05 \mathrm{mg} / \mathrm{kg}(+)$ and Verapamil 2.11 $\mathrm{mg} / \mathrm{kg}(-)$ on serum Alkaline phosphatase (U/L) level in female Wistar OVX rats

The serum Alkaline phosphatase levels significantly $(\mathrm{P}<0.001)$ increased in standard estradiol (283.86 \pm 1.37$)$, Verapamil (296.84 \pm 1.58$)$ and BayK-8644 (298.31 \pm 0.92$)$ treated groups compared to disease control group 253.86 \pm 1.55 . (For results please refer Figure 2).

Effect of Bay-K-8644 $0.05 \mathrm{mg} / \mathrm{kg}(+)$ and Verapamil 2.11 $\mathrm{mg} / \mathrm{kg}(-)$ on bone weight $(\mathrm{gm})$ in female Wistar OVX rats Weight of right tibia was significantly $(\mathrm{P}<0.01)$ high in Bay-K-8644, $0.516 \pm 0.02$ treated group when compared to disease control group 0.421 \pm 0.03 . The bone weight of right tibia is also increased but less significantly $(\mathrm{P}<0.05)$ in Verapamil 0.505 \pm 0.01 and Bay-K-8644 0.516 \pm 0.02 treated groups when compared to sham operated group $0.428 \pm 0.01$.

The bone weight of right femur was non-significantly increased in standard estradiol, 0.661 \pm 0.04 ; Verapamil, $0.683 \pm 0.03$ and Bay-K-8644, $0.7 \pm 0.04$ treated groups compared to disease control group, $0.557 \pm 0.02$. (For results please refer Figure 3).

Effect of Bay-K-8644 $0.05 \mathrm{mg} / \mathrm{kg}(+)$ and Verapamil 2.11 $\mathrm{mg} / \mathrm{kg}(-)$ on bone length $(\mathrm{mm})$ in female Wistar OVX rats

The bone length of right femur $(\mathrm{mm})$ was significantly $(\mathrm{P}<0.001)$ high in Bay-K-8644 39.83 \pm 0.74 and Verapamil $38.83 \pm 0.30$ treated groups when compared to disease control group $34.33 \pm 0.88$.

The bone length of right femur $(\mathrm{mm})$ is also been increased significantly $(\mathrm{P}<0.01)$ in standard estradiol $37.16 \pm 0.7$ treated group when compared to disease control group $36.66 \pm 0.91$.

The bone length of right tibia $(\mathrm{mm})$ was significantly $(\mathrm{P}<0.01)$ high in Bay-K-8644 $43.66 \pm 0.33$ and Verapamil $43.065 \pm 0.65$ when compared to disease control group 40.83 \pm 0.74 . (For results please refer Figure 4).

Effect Bay-K-8644 0.05 mg/kg (+) and Verapamil 2.11 $\mathrm{mg} / \mathrm{kg} \mathrm{(-)}$ on Outer diameter of diaphysis of bone $(\mathrm{mm})$ in female Wistar OVX rats

The outer diameter of diaphysis of right femur bone $(\mathrm{mm})$ was significantly $(\mathrm{P}<0.001)$ more in Bay-K-8644, 12.16 \pm 0.30 and Verapamil $11 \pm 0.44$ when compared to disease control group $7.33 \pm 0.42$. There is also significant rise in diameter of outer diaphysis of right tibia in BayK-8644 $(\mathrm{P}<0.001,8 \pm 0.51)$ and Verapamil $(\mathrm{P}<0.01,7.83 \pm 0.47)$ when compared to disease control group $5.66 \pm 0.42$. (For results please refer Figure 5).

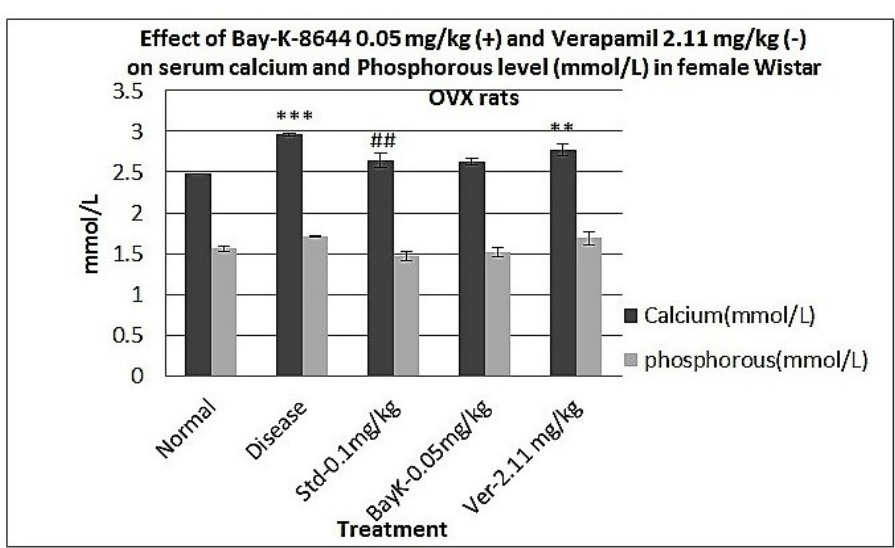

Figure 1: Effect of Bay-K-8644 $0.05 \mathrm{mg} / \mathrm{kg}(+)$ and Verapamil $2.11 \mathrm{mg} / \mathrm{kg} \mathrm{(-)}$ on serum calcium and Phosphorous level $(\mathrm{mmol} / \mathrm{L})$ in female Wistar OVX rats.

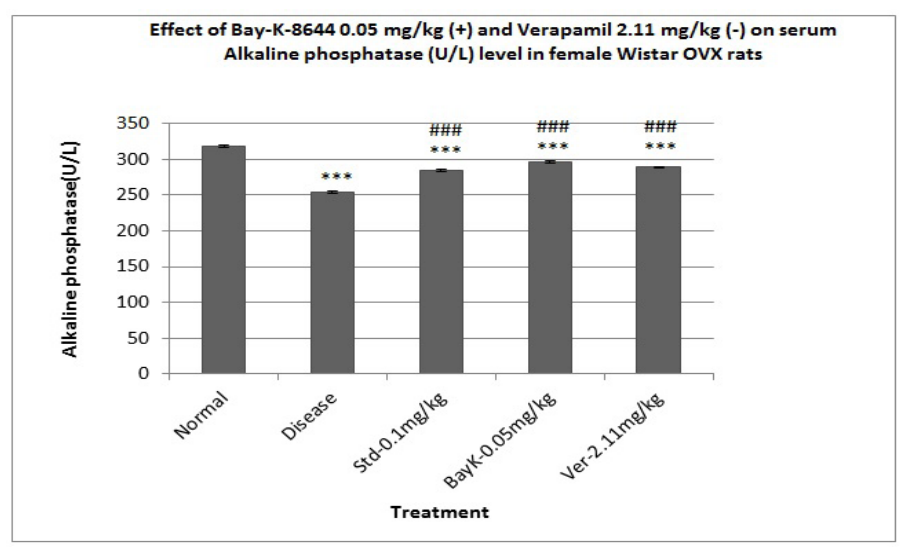

Figure 2: Effect of Bay-K-8644 $0.05 \mathrm{mg} / \mathrm{kg}(+)$ and Verapamil $2.11 \mathrm{mg} / \mathrm{kg}(-)$ on serum Alkaline phosphatase (U/L) level in female Wistar OVX rats.

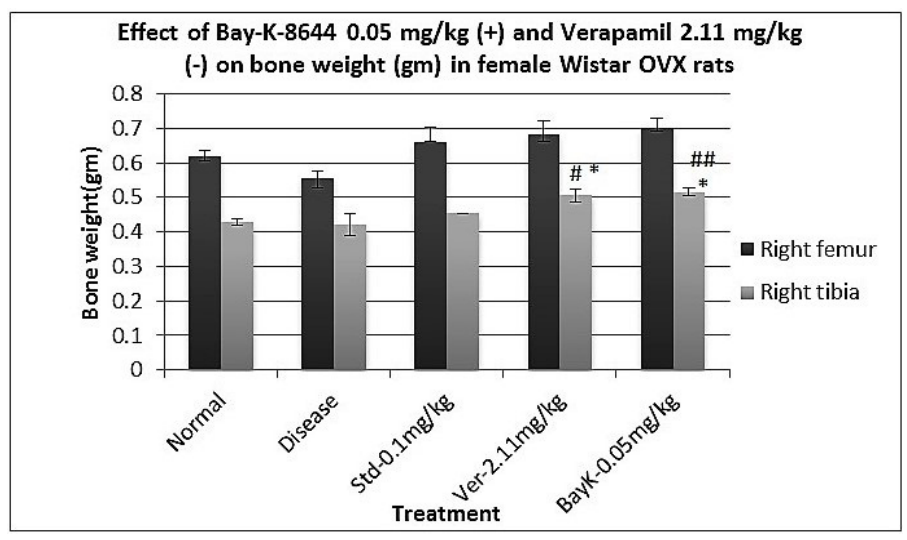

Figure 3: Effect of Bay-K-8644 0.05 mg/kg (+) and Verapamil $2.11 \mathrm{mg} / \mathrm{kg}(-)$ on bone weight ( $\mathrm{gm}$ ) in female Wistar OVX rats.

Effect of Bay-K-8644 0.05 mg/kg (+) and Verapamil 2.11 $\mathrm{mg} / \mathrm{kg}(-)$ on breaking strength ( $\mathrm{N}$ ) of bones in female

\section{Wistar OVX rats}

The breaking strength $(\mathrm{N})$ of $4^{\text {th }}$ lumbar vertebrae, right femur and right tibia was significantly $(\mathrm{P}<0.001)$ high in Bay-K-8644 treated $(14.25 \pm 0.89$; $16 \pm 0.25$ and $17.66 \pm 0.69$ respectively) group compared to disease control group. 
The breaking strength was also found to be significantly high in BayK-8644 treated group for all three mentioned bones compared with normal control group

The breaking strength of $4^{\text {th }}$ lumbar vertebra $(\mathrm{P}<0.05,12.58 \pm 0.85)$, right femur $(\mathrm{P}<0.001,14 \pm 0.25)$ and right tibia $(\mathrm{P}<0.001,17.08 \pm 0.45)$ was found to be significantly high in verapamil treated group compared to disease control group $9.25 \pm 0.54,10.5 \pm 0.34$ and $10.25 \pm 0.55$ respectively. (For results please refer Figure 6).

Effect of Bay-K-8644 $0.05 \mathrm{mg} / \mathrm{kg}(+)$ and Verapamil 2.11 $\mathrm{mg} / \mathrm{kg}(-)$ on Bone mineral density $(\mathrm{g} / \mathrm{cm} 2)$ in female Wistar OVX rats

BMD was found to be significantly high in standard estradiol $(\mathrm{P}<0.01$, $0.201 \pm 0.0012)$, verapamil $(\mathrm{P}<0.05,169 \pm 0.008)$ and Bay-K-8644 $(\mathrm{P}<0.05$, $193 \pm 0.009)$ treated group when compared with disease control group, $153 \pm 0.003$ and normal control group, $184 \pm 0.002$ respectively. (For results please refer Figure 7).

\section{Effect of Bay-K-8644 $0.05 \mathrm{mg} / \mathrm{kg}(+)$ and Verapamil 2.11} $\mathrm{mg} / \mathrm{kg}(-)$ on Ash weight (gm) in female Wistar OVX rats

Ash content of the right femur was found to be significantly $(\mathrm{P}<0.001)$ low in disease control $(0.14 \pm 0.00)$ group compared to normal control group, $0.169 \pm 0.00$. This decrease in the ash value may be because of estrogen deficiency. There was significant $(\mathrm{P}<0.001)$ high weight of the ash value in standard estradiol, $0.188 \pm 0.00$ and Bay-K-8644, 0.195 \pm 0.00

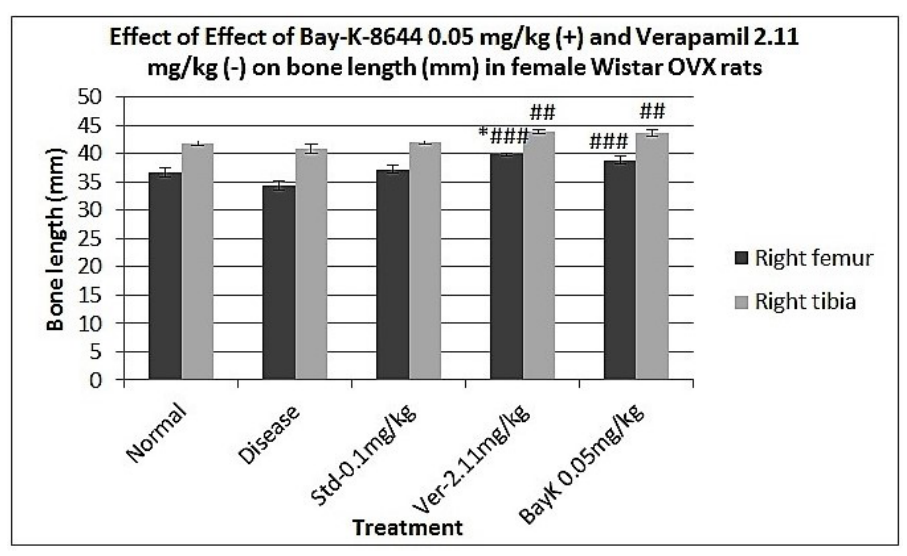

Figure 4: Effect of Bay-K-8644 0.05 mg/kg (+) and Verapamil 2.11 mg/kg (-) on bone length $(\mathrm{mm})$ in female Wistar OVX rats.

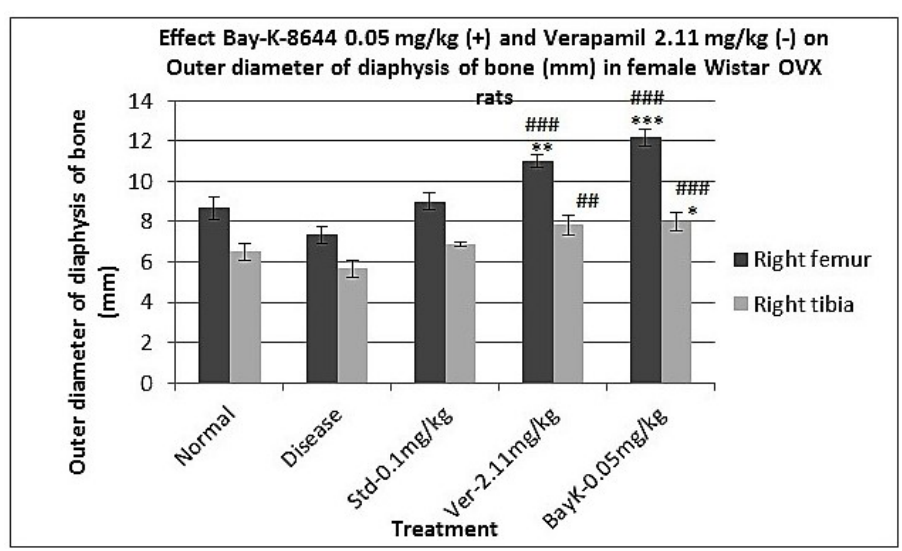

Figure 5: Effect Bay-K-8644 $0.05 \mathrm{mg} / \mathrm{kg}(+)$ and Verapamil $2.11 \mathrm{mg} / \mathrm{kg}(-)$ on Outer diameter of diaphysis of bone $(\mathrm{mm})$ in female Wistar OVX rats. treated group compared to disease control group, $0.140 \pm 0.00$. (For results please refer Figure 8).

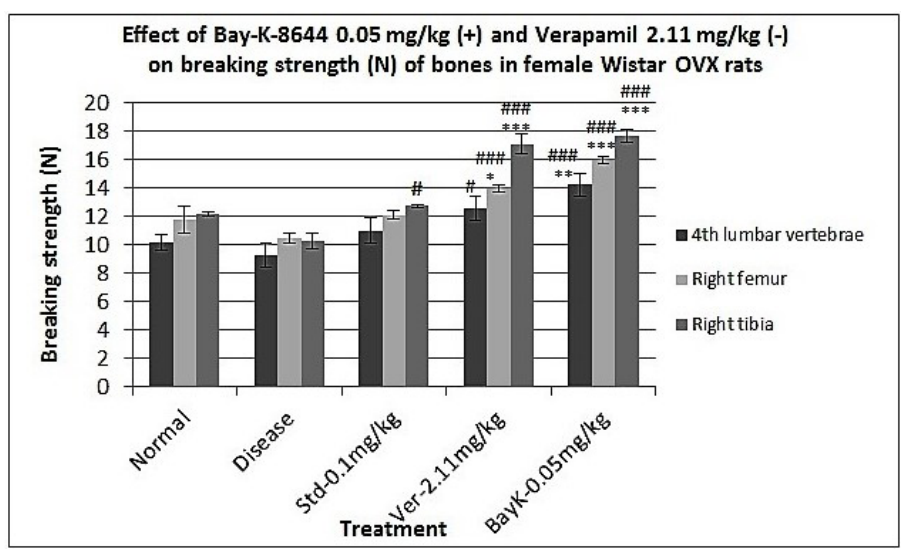

Figure 6: Effect of Bay-K-8644 $0.05 \mathrm{mg} / \mathrm{kg}(+)$ and Verapamil $2.11 \mathrm{mg} / \mathrm{kg}(-)$ on breaking strength $(\mathrm{N})$ of bones in female Wistar OVX rats.

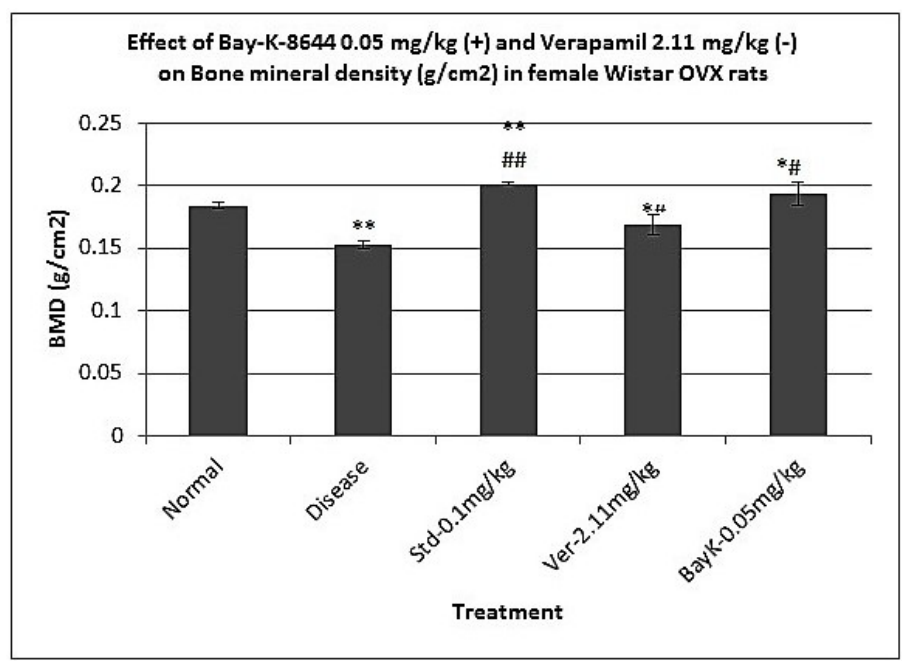

Figure 7: Effect of Bay-K-8644 $0.05 \mathrm{mg} / \mathrm{kg}(+)$ and Verapamil $2.11 \mathrm{mg} / \mathrm{kg} \mathrm{(-)}$ on Bone mineral density $(\mathrm{g} / \mathrm{cm} 2)$ in female Wistar OVX rats.

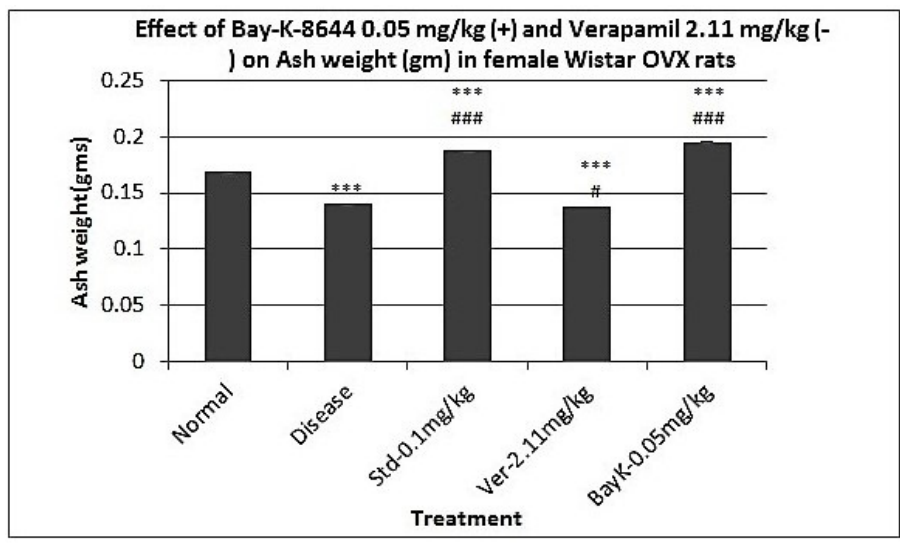

Figure 8: Effect of Bay-K-8644 $0.05 \mathrm{mg} / \mathrm{kg}(+)$ and Verapamil $2.11 \mathrm{mg} / \mathrm{kg}(-)$ on Ash weight (gm) in female Wistar OVX rats. 


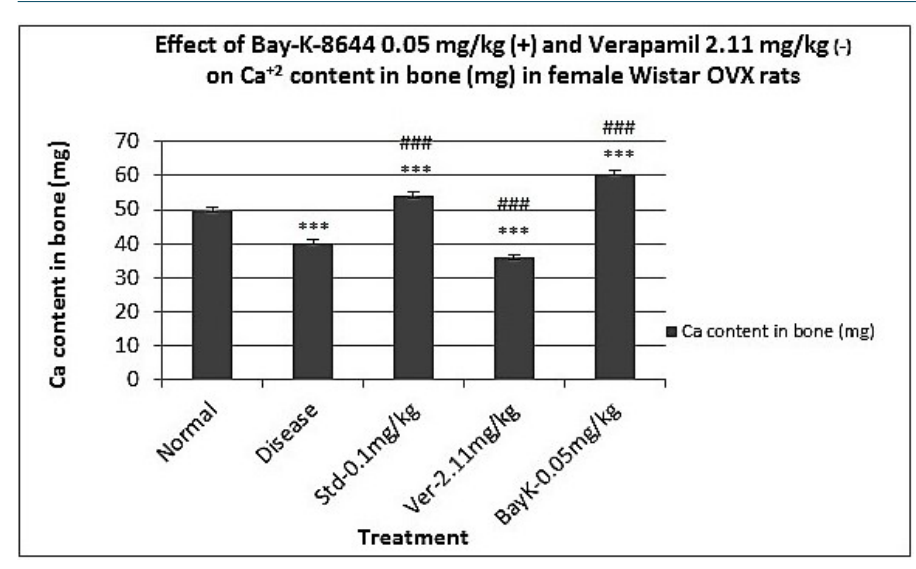

Figure 9: Effect of Bay-K-8644 0.05 mg/kg (+) and Verapamil 2.11 mg/kg (-) on $\mathrm{Ca}^{+2}$ content in bone $(\mathrm{mg})$ in female Wistar OVX rats.

\section{Effect of Bay-K-8644 $0.05 \mathrm{mg} / \mathrm{kg}(+)$ and Verapamil 2.11 $\mathrm{mg} / \mathrm{kg}(-)$ on $\mathrm{Ca}^{+2}$ content in bone $(\mathrm{mg})$ in female Wistar OVX rats}

Calcium $\left(\mathrm{Ca}^{+2}\right)$ content of right femur $(\mathrm{mg})$ was significantly $(\mathrm{P}<0.001)$ decreased in disease control, $39.98 \pm 0.28$ and verapamil $35.77 \pm 0.28$ treated group compared to the sham operated control group, $49.63 \pm 0.2$. The fall in the $\mathrm{Ca}^{+2}$ content was significantly $(\mathrm{P}<0.001)$ elevated by the treatment with standard estradiol, 54.23 \pm 0.83 and Bay-K8644, 60.64 \pm 0.45 treated group as compared to disease control group, 39.98 \pm 0.28 . (For results please refer Figure 9).

\section{DISCUSSION}

According to World Health Organization (WHO), osteoporosis is second only to cardiovascular disease as a global healthcare problem and medical studies show a 50-year-old woman has a similar lifetime risk of dying from hip fracture as from breast cancer. ${ }^{21}$ International Osteoporosis Foundation (IOF) estimates that the annual direct cost of treating osteoporosis fractures of people in the workplace in the USA, Canada and Europe alone is approximately USD 48 billion. ${ }^{22}$

There is an emergent need to treat this problem in cost effective way. Current study has been under taken to compare the effect of CCA (+) and CCB (-) in bone homeostasis and for the treatment of osteoporosis. In the earlier study which was conducted in our lab we have screened few L-types CCB's and verapamil at $2.11 \mathrm{mg} / \mathrm{kg}$ p.o. has come up as lead molecule which has offered optimum protection against ovariectomy induced bone loss model of osteoporosis in female Wister rats. ${ }^{14}$

Although L-type $\mathrm{Ca}^{2+}$ channel-related agents regulate osteoclastic activity. ${ }^{23,24}$ In bone, $\mathrm{Ca}^{2+}$ has a structural role, since osteoblasts deposit an extracellular matrix (ECM) that contains nucleation sites for mineral deposition but their exact role in the control of bone development and resorption is yet to be established. ${ }^{16}$

Ovariectomy induced bone loss is one of the well accepted in-vivo preclinical model for the primary screening of the investigational drugs as it resembles to the human post-menopausal osteoporosis.

Serum $\mathrm{Ca}^{2+}$ levels declined significantly $(\mathrm{P}<0.01)$ in standard estradiol valerate, $2.64 \pm 0.09$ and $(+)$ Bay-K-8644, $2.63 \pm 0.04$ treated groups when compared to disease control group $2.96 \pm 0.01$. The increase in the serum $\mathrm{Ca}^{2+}$ level in the disease control group is may be because of the unavailability of the estrogen to promote the osteoblast division and prevent proliferation and differentiation of osteoclast cells. Because of the lack of estrogen there might be rapid bone turnover and subsequent rise in the serum $\mathrm{Ca}^{2+}$ and $\mathrm{P}$ levels. By the treatment with standard Estrogen restored $\mathrm{Ca}^{2+}$ loss and balanced Osteoclast and Osteoblast phenomenon. By the treatment with agonists (+) Bay-K-8644, $\mathrm{Ca}^{2+}$ loss was restored and low serum $\mathrm{Ca}^{2+}$ level suggesting less calcium turnover. The possible reason for this protective effect of (+) Bay-K-8644 may be mediated through Parathyroid hormone (PTH). Parathyroid hormone regulates serum $\mathrm{Ca}^{2+}$ and $\mathrm{P}^{-}$concentrations through its receptor-mediated, combined actions on bone, intestine and kidney. High levels of PTH, as seen in primary and secondary hyperparathyroidism, increase osteoclastic bone resorption. Low levels, especially if delivered episodically, seem to increase osteoblastic bone formation..$^{25,26}$

Earlier experimental evidence suggests that presence of VDCC exists on parathyroid cell membrane and VDCC respond to plasma calcium. Calcium channels provide a pathway for the movement of calcium across the plasma membrane and that this pool of calcium regulates PTH secretion. Data also suggests that specific VDCC channel agonists like (+) Bay-K-8644 reduced the PTH secretion and antagonists like (-) Verapamil has increases the PTH secretion. ${ }^{27}$ Because of the PTH, bone resorption property the serum $\mathrm{Ca}^{2+}$ is more in Verapamil treated group compared to Bay-K-8644 treated group.

Alkaline phosphate (ALP) is one of the sensitive indicator in osteoporosis so in our study we have investigated the serum ALP level in all groups. The serum ALP levels was significantly $(\mathrm{p}<0.001)$ elevated only by the Bay-K-8644 (296.84 \pm 1.58$)$ treated group but not by the other test groups compared to disease control group $253.86 \pm 1.55$. The increase in the ALP level is indicating the active bone formation phenomenon because ALP is the by-product while osteoblasts cell division along with the matrix formation which provides strength to the bone.

L-type voltage-sensitive calcium channels, Cav1.2 are present on rat osteoblast like cell line which selectively regulate the entry of the calcium ions in osteoblast cells and involved into osteoblastic cell differentiation and bone development phenomenon. ${ }^{28}$ Several lines of evidence have found that bone density increases and that bone resorption decreases when these calcium channels are activated in osteoblasts cells. ${ }^{29}$ (More precisely Verapamil is selective L-type voltage sensitive Calcium channel blocker, Cav1.2 channel which are present on the rat osteoblast cells prevents the calcium entry into the cell and thus may reduce the osteoblast division ALP formation.

On the $41^{\text {st }}$ day of the study we have analyzed the breaking strength of $4^{\text {th }}$ lumbar, right femur and right tibia. Post-menopausal osteoporotic women mainly affected by fractures occurred in femur bone, tibia, $4^{\text {th }}$ lumbar vertebrae that might be because of these bones are mainly involved in support and bear more strain. In our study Bay-K-8644 have shown significant improvement in the breaking strength of $4^{\text {th }}$ lumbar, right femur and right tibia compared with both disease control and sham-operated groups respectively. The results obtained with this regard are as per the earlier literatures with respect to disease control group. Moreover, our histopathological study of femur bone supports our results. As per histopathlogical reports disease control group has shown thinning of trabeculae with tendency of disappearance, loss of connectivity and widening of inter trubular species and less number of the osteoblast cells compared to sham-operated control group. In the standard estrogen treated group microarchitecture of the bone cells are maintained with moderately thick elongated trabeculae and narrowed inter trubular species increased numbers of osteoblasts cells compared to disease control group. Treatment with Bay-K-8644 has also offered protection, no inter tubular species only moderate less osteoclast cells compared with the disease control group. (Refer Figure 10) Along with the bone weight on the same day we have measured the length of right femur and right tibia. Bone length has non-significantly reduced in disease control group compared to normal control group. By the treatment with 


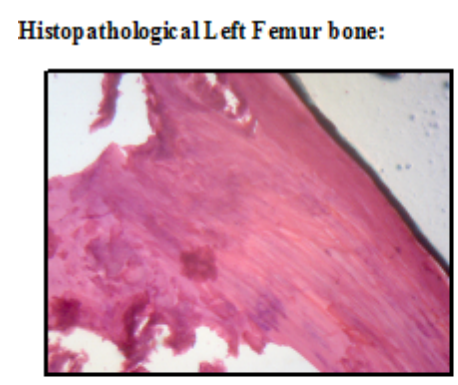

Figure 10 a:

Sham-operated normal Control, $(H \&$ E, x 40).

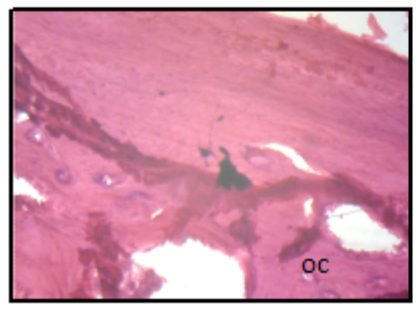

Figure $10 \mathrm{c:}$

Standard Estrogen $1 \mathrm{mg} / \mathrm{kg}$, i.m $(\mathrm{H} \& \mathrm{E}, \mathrm{x} 40)$.

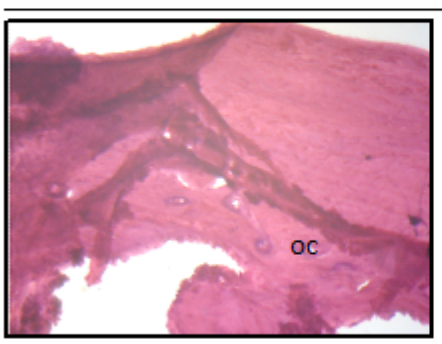

Figure $10 \mathrm{e}$

Bay-K-8644, $0.05 \mathrm{mg} / \mathrm{kg}$, p.o. (H \& E, x 40)

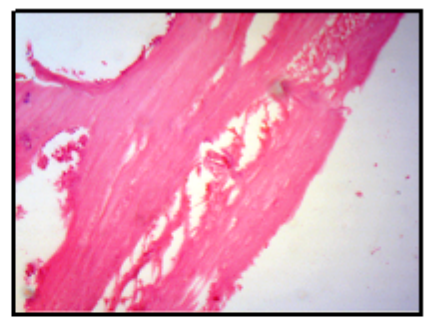

Figure $10 \mathrm{~b}$ :

Disease Control Group (H \& E, x 40).

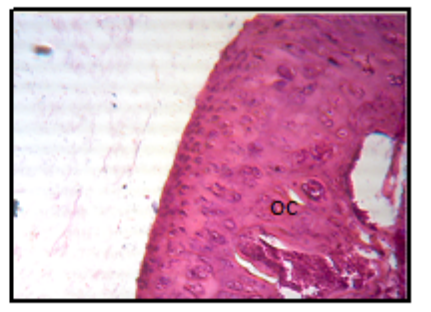

Figure $10 \mathrm{~d}$ :

Verapamil, $2.11 \mathrm{mg} / \mathrm{kg}$, p.o. (H \& E, x 40).
$(+)$ agonist Bay-K-8644 length of right femur and tibia was found to be significantly $(\mathrm{p}<0.001)$ more than disease control group. This protection offered by the (+) agonist Bay-K-8644 is may be because it is the L-type $\mathrm{Ca}^{2+}$ channel opener reduces the RANKL and RANK interaction ${ }^{30}$ and prevents the osteoblasts differentiation so there is less formation of ALP compared to the Verapamil treated group.

Earlier study reveals that by the treatment with VDCC blockers drops osteoprotegerin (OPG) production and upsurge in RANK-L production. Both these proteins are given off by osteoblast cells in response to the serum $\mathrm{Ca}^{2+}$ level.

Moreover, recent in-vitro study also reveals that Bay-K-8644 increases opening frequency, current amplitude and elevate cytosolic $\mathrm{Ca}^{2+}$ in osteoclast cells and decreases RANK-L induced osteoclast formation and also elevate OPG level. ${ }^{31,32}$

Taken together both Calcium channel (-) antagonist and (+) agonist have protective effects on OVX induced bone loss. The differences for the protective effect against OVX-induced bone loss is varies in between Calcium channel (+) agonists and (-) antagonist because of their target sites. Effects of these drugs may also depends upon the quantity of the $\mathrm{Ca}^{2+}$ ions into the osteoblast cells. Osteoblasts cells needs $\mathrm{Ca}^{2+}$ ions for activation but at the same time overloading of these cells with $\mathrm{Ca}^{2+}$ ions may activate the apoptotic pathway that causes cell death.

Ironically, before come to the final conclusion more precise study has to be done with respect to the selection of test drug dose, duration of drug treatment and in-vivo and in-vitro studies has to be run simultaneously. Based upon our finding our results are more inclined towards Bay$\mathrm{K}-8644$ but more studies are needed to understand precise mechanism and side effects before implementing into the human subjects.

\section{CONCLUSION}

Ironically, before come to the final conclusion more precise study has to be done with respect to the selection of test drug dose, duration of drug treatment, in-vivo and in-vitro studies has to be run simultaneously. Based upon our finding our results are more inclined towards BayK-8644 but more studies are needed to understand precise mechanism and side effects before implementing into the human subjects.

\section{ACKNOWLEDGEMENT}

The author (s) deeply acknowledges to the Principal and management of CMR college of Pharmacy, Hyderabad, India for providing laboratory facilities to carry out this study successfully.

\section{CONFLICT OF INTEREST}

Authors don't have any conflict of interest.

\section{ABBREVIATION USED}

ALP: Alkaline phosphate; BMD: Bone mineral Density; Cav: Voltage activated Calcium Channel; CCA: Calcium Channel Agonists; CCB: Calcium channel Blockers; CPCSEA: Committee for the Purpose of Control and Supervision of; DEXA: Dual-Energy X-Ray Absorptiometry; ECM: Extracellular Matrix; IAEC: Institutional Animal ethical Committee; IOF: International Osteoporosis Foundation; NFATc1: Nuclear factor of activated T cells cllear factor of activated T cells c1; OPG: Osteoprotegerin; OVX: Overactomy; PTH: Parathyroid Hormone; RANK: Receptor activator of nuclear factor kappa; RANKL: Receptor activator of nuclear factor kappa ligand; U.S. FDA: United States Food and drug administration; VDCC: Voltage dependent Calcium channels; WHO: World Health Organization. 


\section{REFERENCES}

1. Drake MT, Clarke BL, Lewiecki EM. The Pathophysiology and Treatment of Osteoporosis. Clin Ther. 2015;37(8):1837-50.

2. Brunton, Chabner, Knollman. Goodman and Gilman's The Pharmacological Basis of Therapeutics. United States of America. The McGraw-Hill Companies Publishers. 2011.

3. Guggino SE, Lajeunesse D, Wagner JA, Snyder SH. Bone remodeling signalled by a dihydropyridine- and phenylalkylamine-sensitive calcium channel. Proc Nat Acad Sci USA. 1989;86(8):2957-60.

4. Morain P, Peglion JL, Giesen-Crouse E. $\mathrm{Ca}^{2+}$ channel inhibition in a rat osteoblast-like cell line, UMR 106, by a new dihydropyridine derivative, S11568. Eur J Pharmacol. 1992;220(1):11-7.

5. Li Z, Kong K, QiW. Osteoclast and its roles in calcium metabolism and bone development and remodeling. Biochem Biophys Res Commun. 2006;343(2):34550.

6. Mentaverri R, Yano S, Chattopadhyay N, Petit L, Kifor O, Kamel S, et al. The calcium sensing receptor is directly involved in both osteoclast differentiation and apoptosis. FASEB J. 2006;20(14):2562-4

7. Negishi-Koga T, Takayanagi $\mathrm{H}$. $\mathrm{Ca}^{2+}-N F A T c 1$ signaling is an essential axis of osteoclast differentiation. Immunol Rev. 2009;231(1):241-56.

8. Long S M N, Hyojung P, Ting Zheng, Hyun-II Ha, Mijung Yim. L-type $\mathrm{Ca}^{2+}$ channel agonist inhibits RANKL-induced osteoclast formation via NFATc1 downregulation. Life Sciences. 2011;89(5-6):159-64.

9. Ritchie CK, Maercklein PB, Fitzpatrick LA. Direct effect of calcium channel antagonists on osteoclast function: alterations in bone resorption and intracellular calcium concentrations. Endocrinology. 1994;135(3):996-1003.

10. Kentarou U, Yuwang Liu, Tomohiro M, Eiko I, Yuya M, Hitoshi A, et al. Protective effect of amlodipine against osteoporosis in stroke-prone spontaneously hypertensive rats. European Journal of Pharmacology. 2010;635(1-3):227-30.

11. Goldman JM, Murr AS, Cooper RL. The rodent estrous cycle: characterization of vaginal cytology and its utility in toxicological studies. Birth Defects Research. 2007;80(2):84-97.

12. Kulkarni SK. Hand book of experimental Pharmacology New Delhi, India: Vallabh Prakashan publisher. 2011

13. Chitme HR, Muchandi IS, Burli SC. Effect of Asparagus Racemosus Wild Root Extract on Ovariectomized Rats. The Open Natural Products Journal. 2009;2:1623.

14. Vijay RC, Abdulkhaliq JA, Sibghatullah MAS. Effect of Voltage-Gated Calcium Channels (Cav) Blocker on Ovariectomy Induced Osteoporosis in Rats. Journal of Young Pharmacists. 2016;8(3):436-46.

15. Bourson A, Gower AJ, Mir AK, Moser PC. The effects of dihydropyridine compounds in behavioural tests of dopaminergic activity. $\mathrm{Br} \mathrm{J}$ Pharmacol. 1989;98(4):1312-8.

16. U.S. Department of Health and Human Services Food and Drug Administration Center for Drug Evaluation and Research (CDER) June 2016 Pharmacology/ Toxicology.

Article History: Submission Date: 18-09-16; Received Date: 01-10-16; Acceptance Date: 13-01-17.

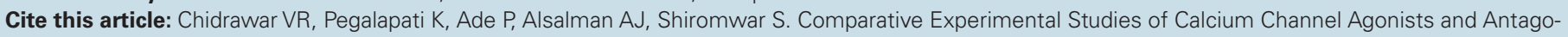
nists against Ovariectomy Induced Osteoporosis In Rats. J Young Pharm. 2017;9(2):239-45.
17. Cora MC, Kooistra L, Travlos G. Vaginal Cytology of the Laboratory Rat and Mouse: Review and Criteria for the Staging of the Estrous Cycle Using Stained Vaginal Smears. Toxicol Pathol. 2015;43(6):776-93.

18. Miller GW, Burtis CA, Ash wood ER, Saunders WB Eds. Mineral and bone me-

19. Ammann P, Rizzoli R, Slosman D, Bonjour JP. Sequential and precise in vivo measurement of bone mineral density in rats using dual-energy $x$-ray absorptiometry. J Bone Miner Res. 1992;7(3):311-6.

20. Magda MN. Histological assessment of zoledronic acid (Aclasta) in protection against induced osteoporosis in female albino rats. The Egyptian Journal of Histology. 2011;34(1):129-38.

21. India Times. (2004). Boninh upon Osteoporosis. http://health.indiatimes.com/ articleshow/329953.cms. Accessed on $2^{\text {nd }}$ Sep 2015.

22. International Osteoporosis Foundation. (2014). Osteoporosism Fact Sheet https://dolcera.com/wiki/images/Osteoporosis_factsheet.pdf. Accessed on 2nd Oct 2014.

23. Miyauchi A, Hruska KA, Greenfield EM, Duncan R, Alvarez J, Barattolo R, et al. Osteoclast cytosolic calcium, regulated by voltage-gated calcium channels and extracellular calcium, controls podosome assembly and bone resorption. J Cell Biol. 1990;111(6 Pt 1):2543-52.

24. Zhang X, Li F, Guo L, Hei H, Tian L, Peng W, et al. Forskolin Regulates LType Calcium Channel through Interaction between Actinin 4 and $\beta 3$ Subunit in Osteoblasts. PLoS One. 2015;10(4):e0124274.

25. Teitelbaum SL, Ross FP. Genetic regulation of osteoclast development and function. Nat Rev Genet. 2003;4(8):638-49.

26. Cohen MM Jr. The new bone biology: pathologic, molecular, clinical correlates. Am J Med Genet A. 2006:140(23):2646-706.

27. Pocotte SL, Ehrenstein G, Fitzpatrick LA. Role of calcium channels in parathyroid hormone secretion. Bone. 1995;16(4 Suppl):365-72

28. Katzung BG, Masters SB, Trevor AJ. (2009). Basic \& Clinical pharmacology. Ed. 9 New Delhi. Mcgraw Hill publishers.

29. Zhongyang $S$, Xinsheng $C$, Zhuo Z, Zebing $H$, Lianchang $Z$, Han W, et al. Simulated microgravity inhibits L-type calcium channel currents partially by the upregulation of miR-103 in MC3T3-E1 osteoblasts. Sci Rep. 2015;28(5):8077.

30. Robbins SL, kumar V, Abbas AK, Fausto N, Mitchell. Robbins basic Pathophysiology. India. Elsevier publishers. 2007.

31. Noh AL, Park $\mathrm{H}$, Zheng $\mathrm{T}$, $\mathrm{Ha} \mathrm{HI}$, Yim M. L-type $\mathrm{Ca}^{+2}$ channel agonist inhibits RANKL- induced osteoclasts formation via NFATc1 down regulation. Life Sci. 2011;89(5-6):159-64

32. Bergh JJ, Xu Y, Farach-Carson MC. Osteoprotegerin expression and secretion are regulated by calcium influx through the L-type voltage-sensitive calcium channel. Endocrinology. 2004;145(1):426-36 tabolism, In Tietz textbook of clinical chemistry, Philadelphia, 1994. 